\title{
A kriminálpolitika kapcsolata a magyar közszolgálati szervezetek migrációs tevékenységével
}

\section{SZABÓ László András ${ }^{1}$}

\begin{abstract}
A 2015. évi tömeges bevándorlás hatása leginkább a kriminálpolitika megváltozásán és ezzel összefüggésben a közigazgatási és rendészeti szervek migrációval foglalkozó szervezeteinek tevékenységében tapasztalható. Ezen szervezeteket alapvetően nem ilyen nagyságú és intenzitású migrációs nyomásra alakították ki, sem létszámban, sem infrastruktúrában. A Dublin III. ${ }^{2}$ rendelet, amelyet Magyarország is aláirt 2015 januárjában lépett hatályba két-háromszázezer menekült befogadását irányozta elő az egész Európai Unióban. Tanulmányomban a magyar migrációval foglalkozó közszolgálati szervezeteket és a kriminálpolitika kapcsolatát vizsgálom.
\end{abstract}

Kulcsszavak: kriminálpolitika, közszolgálati szervezetek, tömeges bevándorlás, válsághelyzet

\section{Bevezetés}

A 2015. évi tömeges bevándorlás hatása leginkább a kriminálpolitika megváltozásán és ezzel összefüggésben a közigazgatási és rendészeti szervek migrációval foglalkozó szervezeteinek tevékenységében tapasztalható. Ezen szervezeteket alapvetően nem ilyen nagyságú és intenzitású migrációs nyomásra alakították ki, sem létszámban, sem infrastruktúrában. A Dublin III. ${ }^{3}$ rendelet, amelyet Magyarország is aláírt 2015 januárjában lépett hatályba két-háromszázezer menekült befogadását irányozta elő az egész Európai Unióban. A magyarországi közszolgálati szervezetek feladata kettős, mert egyrészt meg kell felelni az adott helyzetnek, másrészt fel kell készülni a várható jövőbeni migrációs hatásokra, mindezt az állampolgárok elvárásának megfelelően, a közbiztonság tekintetében. Azt a változást mutatom be, ami a magyar közszolgálati szervezetek, az államigazgatás, a rendészeti szervezetek és a honvédség esetében történt a 2015. évi tömeges bevándorlás következtében. Fókuszba a rendőrséget és a közigazgatást helyezem. Vizsgálom, hogyan hatott a rendészeti szervezetek létszámára

\footnotetext{
Szabó László András, Nemzeti Közszolgálati Egyetem Közigazgatás-tudományi Doktori Iskola, doktorandusz. László András Szabó, University of Public Service Doctoral School of Public Administration Sciences, PhD student. E-mail: szabo.laszlo.andras@uni-nke.hu, ORCID: https://orcid.org/0000-0001-7957-0724

Országos Idegenrendészeti Főigazgatóság: Dublini eljárás. é. n.

Országos Idegenrendészeti Főigazgatóság (é. n.) i. m.
} 
a műszaki határzár kialakítása a magyar-szerb határon, hivatalos nevén a határőrizeti célú ideiglenes kerítés. Tény, hogy nincsenek migránsok Magyarország területén, mint azt 2015-ben tapasztaltuk, mégis az állami szervezetek a határőrizetből eredő kötelezettségük okán folyamatos létszámproblémákkal néznek szembe. Értelmezem az elrettentés elméletét, majd az illegális bevándorlást és a bevándorlási jog kriminalizálását, vagyis a „crimmigration” jelenségét mutatom be. Az ENSZ előrejelzése a migráció folyamatos növekedését prognosztizálja globális szinten. Ez már nem nevezhető hagyományos, megszokott migrációnak, hiszen a környezet megváltozása a demográfiai növekvő pályán van a fejlődő országokban, az erőforrások csökkennek, ezzel párhuzamosan az igények növekednek. Mindez elég egyértelmúen az embereket oda irányítja, ahol jobb életet, egészségesebb környezetet és biztonságosabb életkörülményeket találnak.

\section{A migráció fogalma és kapcsolata az állammal}

A migrációnak sok meghatározása, fogalma létezik a tudományos világban. A leginkább átfogó megfogalmazásban a migráció egy olyan folyamat, amelyben a személyek lakóhelyet, illetve társadalmat váltanak oly módon, hogy ez a váltás átmeneti vagy tartós marad. ${ }^{4}$ A népességmozgás tipikus esete az évszázadok óta zajló munkaerő-migráció. Emellett a munkavállalási szándék mellett számos tényező növeli a migrációs hajlandóságot. Ugyancsak évszázados, talán inkább évezredes múltja van a vallási, etnikai, politikai üldözöttek migrációjának. Az utóbbi időben egyre inkább megfigyelhető a migrációs motivációkban a politikai és gazdasági tényezők keveredése. A migráció kezelésében az állam lehet beengedő irányultságú, vagyis nyitott, erre példa Németország. Lehet elrettentő, vagyis zárt irányultságú, mint ÉszakKorea, illetve lehet az előző kettő keveréke, mint amilyen Magyarország. Az államok lehetnek kibocsátó országok, mint Szíria, befogadó, vagyis célországok, mint Németország, illetve tranzitország, mint amilyen Magyarország. Hagyományosan azt a felosztást szokták használni, hogy a migrációnak két oldala van, a kivándorlás és a bevándorlás. Napjainkban ehhez egy harmadik oldal is társul, a tranzitvándorlás vagy átvándorlás. Ez azt jelenti esetünkben, hogy Magyarország a kibocsátó és a befogadó országok között mintegy átkelőország szerepel. Így a migránsok (a szóba beleértem a jogi és a nem jogi kategóriákat is) egyszerűen csak át akarnak kelni, mintegy leküzdésre váró akadályként hazánkon, tehát az előzmények, amelyek megismerése az elrettentés céljának tisztázása érdekében szükségesek, a migráció növekedésével vannak összefüggésben. Ezek az illegális migráció tekintetében a következőképpen alakultak a statisztikai adatok szerint.

Póczik Szilveszter: Nemzetközi migráció - biztonságpolitikai, rendészeti aspektusok. In Tarrósy István - Glied Viktor - Keserủ Dávid (szerk.): Új népvándorlás: Migráció a 21. században Afrika és Európa között. Pécs, Publikon, 2011. 35-51. 


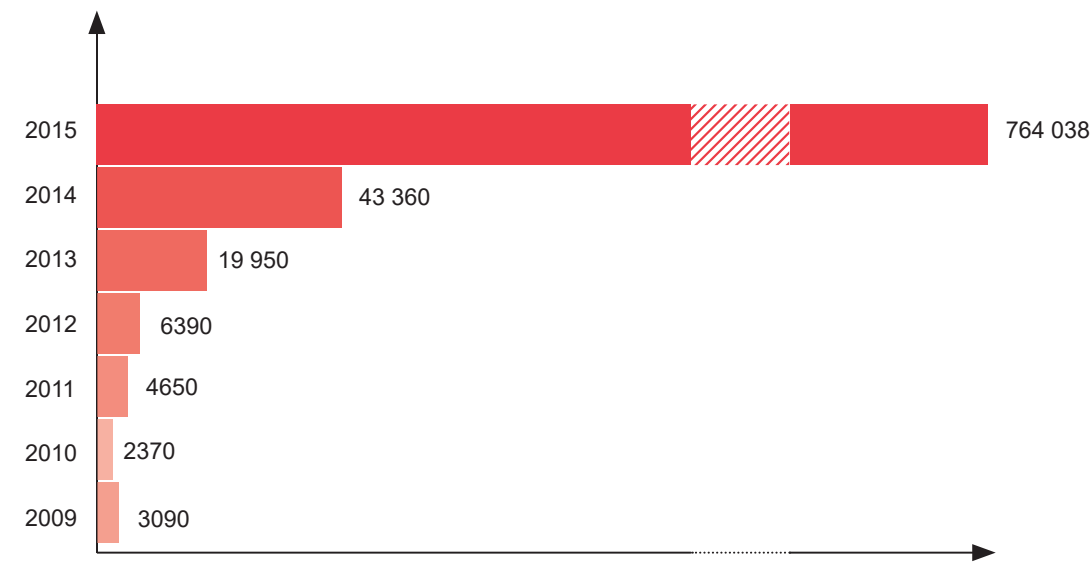

1. ábra: A tiltott határátlépések dinamikája a Nyugat-balkáni útvonalon 20092015 között - ezer föben kifejezve. Forrás: Frontex.eu ${ }^{5}$

Az 1. ábra alapján, a Frontex, azaz az Európai Határ- és Partvédelmi Ügynökség kimutatásán jól követhető az illegális határátlépések számának változása a nyugat-balkáni útvonalon 2009-2015 között. 2009-ben 3090 fö, 2010-ben 2370 fö, 2011-ben 4650 fö, 2012-ben 6390 fő, 2013-ban 19950 fő, 2014-ben 43360 fö, 2015-ben 764038 fő. A növekedés drasztikus, miközben tényleges intézkedések abban az időszakban nem történtek európai uniós szinten.

Magyarország tekintetében ez a növekedés 2015-ben a következő változást mutatja.

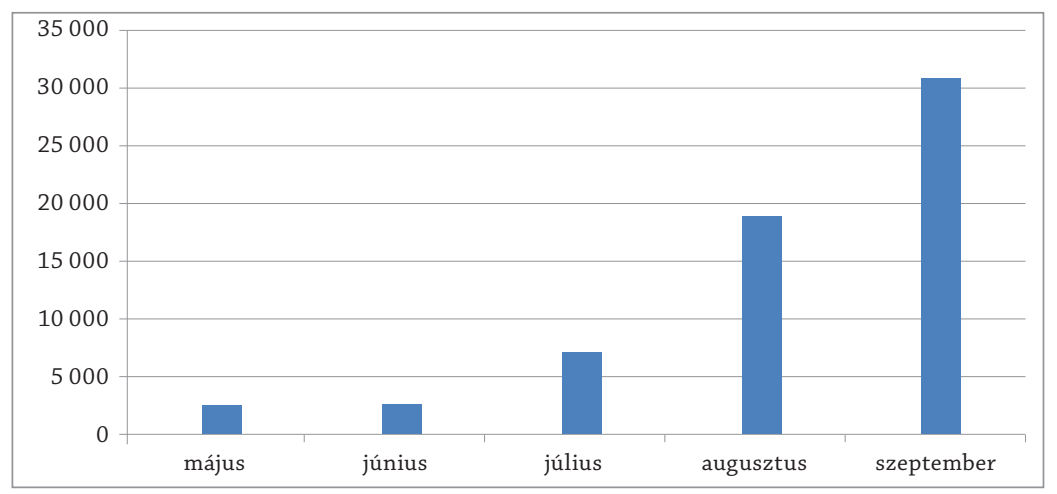

2. ábra: A migráció növekedése Magyarországon: az elfogott migránsok száma 2015. május és szeptember között - ezer föben kifejezve. Forrás: Police.hu Elfogott migránsok-dátum szerinti lekérdezés alapján a szerző szerkesztése ${ }^{6}$

\footnotetext{
Frontex.eu

6 Határrendészeti helyzetkép 2015. május-szeptember. Online: www.police.hu/a-rendorsegrol/statisztikak/hatarrendeszet?page $=6$
} 
A 2. ábra, illetve A Magyar Rendőrség hivatalos oldalának az adatai is ezt jól mutatják. A tiltott határátlépések számának növekedése havi megoszlásban 2015 során május 31-én 2735 fô, június 30-án 7226 fő, július 31-én 10677 fő, augusztus 30-án 19069 fő, szeptember 30-án 30949 fő volt. Az ideiglenes határzárvédelem felállítása után ez a szám drasztikusan csökkent, egy-két fő és 30 fő között mozgott, majd stagnált. Egy-egy kiugróbb átlépés mellett, ami 250 főt jelent napi szinten. Felmerül a kérdés, hogy vajon a kialakított fizikai eszközök, az ideiglenes technikai határzár és a jogi határzárvédelem együttesen alkalmasak lehetnek-e a migráció megállítására. Az igazság, hogy nem alkalmasak. Nem is lehet ezt a célt elvárni tőlük. Csak a lelassítására. Ahogy azt Ritecz György és Sallai János megfogalmazza: „Tudománytalanok lennénk, ha nem látnánk be, hogy a kerítés valóban megoldás, de nem az illegális migráció kezelésére, hanem annak egy adott határszakasztól, egy adott régiótól való időszakos elterelésére."7 A kijelentés egybecseng a szituációs bűnmegelőzés esetén az úgynevezett áttevődés, áthelyeződés jelenségével. Vagyis, hogy az elkövető, mivel nem éri meg neki a tett elkövetése, azt máshol próbálja meg végrehajtani. Véleményem szerint a kerítés feladata a migrációt megfelelő irányba terelve a migránsokat a tranzit zónához irányítani, ahol a rendészeti szervezetek munkatársai az eljárást kérelemre el tudják indítani.

\section{A migráció kezelésében részt vevő közszolgálati szervezetek}

„A közszolgálati szervezet valóságos működési funkciókkal rendelkező, célszerűségi elven szerveződő, aktív tevékenységet folytató, jellemzően nem értéktermelő folyamatokat végrehajtó szervezet. A közszolgálati szervezetekhez soroljuk az államigazgatási, a honvédségi és a rendészeti szerveket." ${ }^{8}$ Szinte nincs olyan szervezet, amelyet kisebb-nagyobb mértékben ne érne a migráció hatása. Ez lehet költség, kiadás, létszámgazdálkodás, jogalkotás. A Magyar Honvédség is komoly részt vállal a határ védelmében, és közös nemzetközi missziókban vesz részt (ilyen például az Észak-Macedónia határvédelmében történő besegítés). A határvédelmi járőrözésben is részt vesz 500 fővel. Dr. Böröndi Gábor altábornagy, a Magyar Honvédség parancsnokának helyettese tájékoztatása szerint a honvédség megkezdte a személyi állomány és a szükséges technikai eszközök átcsoportosítását. Mint fogalmazott: a korábban váltásonként 50 fős kerettel járőröző katonák létszámát január 6-tól 100-ra emelik, de a kiszolgáló személyzettel együtt, összesen több mint 500 főre növeli a Magyar Honvédség a rendőrség támogatását. ${ }^{9}$

Ritecz György - Sallai János: A migráció trendjei, okai és kezelésének lehetőségei. 2.0. Budaörs, Hanns Seidel Alapítvány, 2016. 199.

8 Czuprák Ottó - Kovács Gábor: A szervezetvezetés elmélete. A közszolgálati szervezetek vezetésének elméleti alapjai. Budapest, Dialóg Campus, 2017.179.

9 Honvedelem.hu 
Azok a rendészeti szervezetek vannak kitéve leginkább a hazánkra nehezedő migrációs nyomásnak, amelyeknek egyrészt kötelességük a védelem mint állami feladat, másrészt az egyén tőlük várja a biztonság fenntartását.

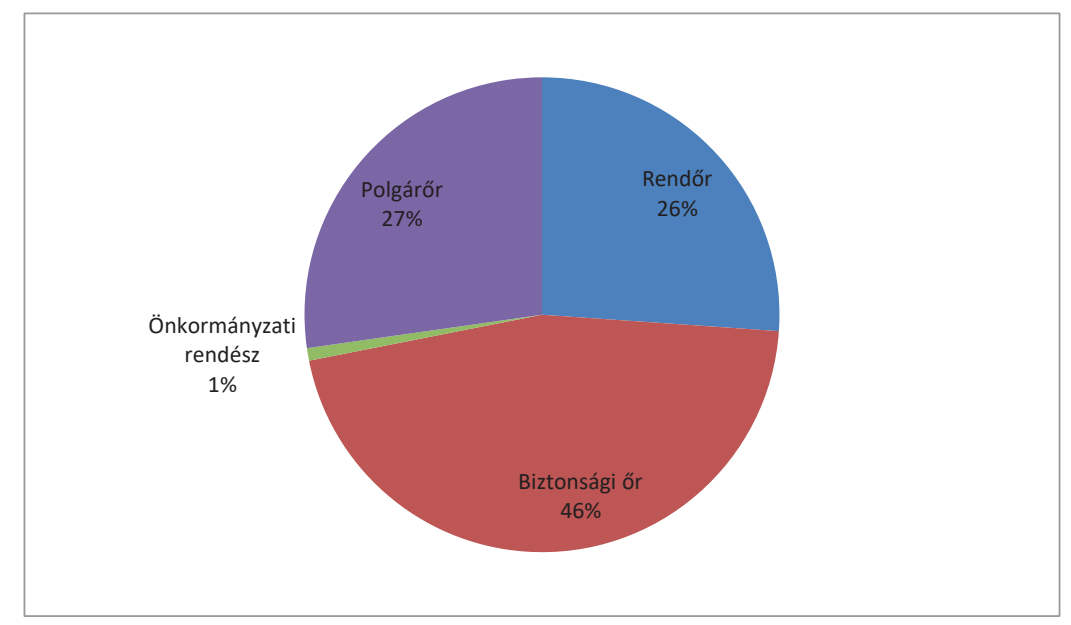

3. ábra: Rendészeti szervezetek létszámmegoszlása \%-ban. Forrás: Szabó László András: A migráció hatása a közigazgatásra. Magyar Rendészet, 17. (2017), 1. 166.

A 3. ábrának megfelelően a létszámadatok: biztonsági őr 84094 (fő), rendőr 48 ezer (fő), önkormányzati rendész 1563 (fő), polgárőr 50 ezer (fő), összesen 183657 (fő). A Polgárőr Szövetség és szervezetek ebben különleges helyet foglalnak el, mivel önként, szabadidőben, díjazás nélkül végzik a tevékenységüket. Ennél erősebb megnyilvánulása a közösség felé érzett felelősségnek tágabban az egész ország, még tágabban a haza iránt érzett elkötelezettségnek csak a hivatásos rendőri szervezetek tagjainál figyelhető meg. Christián László így fogalmazza meg: „A polgárőrség mára a közbiztonság egyik fő letéteményese, a rendőrség, a rendvédelmi és rendészeti szervek, továbbá a helyi önkormányzatok stratégiai partnere, szövetségese lett, jelentős és tevékeny részt vállalva a bűncselekmények megelőzéséből, az állampolgárok szubjektív biztonságérzetének javításából." ${ }^{10}$ A migráció kezelésében a legfontosabb szereplő a Bevándorlási és Állampolgársági Hivatal, amely 2017. január 1-jétől Bevándorlási és Menekültügyi Hivatalként múködött, majd 2019. július 1-jétől az eddigi közigazgatási szervezetből rendészeti szervezetté alakult át. A köztisztviselőkből pedig hivatásos rendőrök lettek. A tevékenységhez és a szervezethez megfelelően a neve is megváltozott, Országos Idegenrendészeti Főigazgatóság lett. Az átalakulás összhangban van a kriminálpolitika megváltozásával és a migráció kezelésének menedzserszemléletével, illetve az elrettentés elméletének a bevándorlás kezelésében történő megjelenésével.

10 Christián László: A helyi rendészeti együttmüködés rendszere. Iustum Aequm Salutare, 16. (2012), 1. 45. 


\section{A kriminálpolitika megváltozása és következményei}

A kriminálpolitika fogalma adja meg azt a keretet, amelyben a jelenséget értelmezni tudjuk. Franz von Liszt 1905-ben írt megfogalmazásában „[a] bűnözés okait és hatásait vizsgáló diszciplina, amely megszabja a bünözéssel szembeni állami fellépés határait". ${ }^{11}$ A kriminálpolitika a bünügyi tudományokból a bűnügyi jogtudományokkal, vagyis a büntetőjog, büntető eljárási jog és büntető-végrehajtási jog, illetve a nem jogi tudományok, a kriminológia, kriminálpszichológia és a kriminalisztika területeihez kapcsolódik, mintegy összeköti és keretbe foglalja azokat. A kriminálpolitika alrendszerei a következők: a rendészeti politika, a bűnmegelőzési politika, az áldozatvédelmi politika, a büntetőpolitika, a büntetőjog-politika a büntető igazságszolgáltatási politika és a büntetés-végrehajtási politika. ${ }^{12} \mathrm{~A}$ kriminálpolitika keretében jelenik meg az elrettentés elmélete. Ez az elmélet kiemelten fontos, mert irányt szab és keretet ad a migráció kezelésében részt vevő közszolgálati szervezetek tevékenyégének.

\section{Az elrettentés elmélete}

Ahhoz, hogy megértsük az elrettentés dogmatikáját, vissza kell nyúlnunk ahhoz a tételhez, amelyben megszületett. Ez Borbíró Andrea megfogalmazásában: „A klasszikus paradigma az akaratszabadság tételén alapul. Az embert olyan racionális, szabadon cselekvő egyénnek tekinti, akinek magatartását, döntéseit csupán saját jól felfogott önérdeke alakítja. A klasszikus paradigma szerint ezért a bűnözésnek nincsen különösebb oka azon túl, hogy egyének saját érdekeiket követve úgy döntenek, hogy búncselekményeket követnek el, mert ez nekik valamiért jó, azaz megéri (ezért hívják az ide tartozó kriminológiai elméleteket döntési vagy akarati elméleteknek is)." ${ }^{13}$ A büntetés elkerülhetetlensége adja annak visszatartó erejét. Ezen elvek Cesare Beccaria (1778) A bünökrôl és büntetésekrôl ${ }^{14}$ című munkájában jelennek meg. Ez volt az úgynevezett klasszikus paradigma kialakulása. Ez a büntetőpolitika sokáig háttérbe szorult. Majd az 1970-es évektől fokozatosan a jóléti államok válsága és összeomlása után újra előtérbe került. Ezt hívjuk neoklasszikus büntetőpolitikai fordulatnak és 1984-re datálható. Megjelent a rendteremtő vagy más néven rendfenntartó állam, és az elrettentés dogmatikailag is ekkor került újra a fókuszba. Jellemzően párban szokták emlegetni a semlegesítéssel, vagyis a személy vagy a tett semlegesítésével. Felmerül a kérdés, hogy vajon magát az elrettenést mi alapozza meg. Egy jelenség, mint a búnözés nagyságának hirtelen megváltozása, amely változást a felderítések száma nem tud követni. Magyarországon 1985-1992 között a regisztrált bűncselekmények száma négyszeresére emelkedett, és a gazdasági-társadalmi változások az oksági folyamatokat is

\footnotetext{
1 Gönczöl Katalin - Kerezsi Klára - Korinek László: Kriminológia - Szakkriminológia. Budapest, CompLex, 2007. 601.

Borbíró Andrea et alii: Kriminológia. Budapest, Wolters Kluwer, 2017. 716.

Borbíró et alii (2017) i. m. 36.

14 Cesare Beccaria: A bünökröl és a büntetésekröl. Budapest, Attractor, 2012. 112.
} 
jelentősen átalakították. ${ }^{15}$ Szabó András kriminológus 1992-ben írta meg az Igazságosan vagy okosan? című könyvét, amelyben az ötödik fejezetet szentelte az elrettentés körbejárásának. Szabó András így vezette le az elrettentés elméletét, amely a következő részekből áll: fenyegetés, fenyegetés beváltása, választási lehetőség és felelősség, előnyök és hátrányok egyenlege, bizonyosság és szigor (elkerülhetetlenség). ${ }^{16}$ Minden büntetésnek van generális és speciális elrettentő hatása. Itt a generális büntetésnek a potenciális bűnelkövetők a címzettjei. Speciális büntetés a már megbüntetett személyre hat. Szabó András értelmezéséből tökéletesen látszik, hogy a rendőrségi létszám és a felderítések száma nem képes lépést tartani a regisztrált bűncselekmények számának növekedésével, viszont a társadalmi elvárás jelentős nyomás alá helyezi a rendészeti szervezeteket. Vagyis megjelenik az állami cselekvési kényszer, amely utat nyit a paradigmaváltásnak. Ez pedig az elrettentés jellemzői közül a legfontosabb, a tett alapú büntetés, amely egyben tettarányos is. Bűntett és büntetés. Nem nézi sem az elkövető, sem az elkövetés pszichológiai, szociológiai vagy kulturális körülményeit. Nagyon jól alkalmazható a hirtelen megnövekedő jelenségek, mint a bűnözés vagy a migráció kezelésére, ez tény. Generális prevenciójú, így mindenkire ugyanúgy érvényes gyors és látványos eredménnyel jár. Relatíve olcsó, mert nem igényel komolyabb szervezetfejlesztést, csupán az egyszeri technikai beruházás szükséges. Büntetőjogilag valamennyi visszatartóereje van, és bűnmegelőző hatásáról beszélhetünk, de nem a bűnmegelőzés klasszikus hármas tagolásának az értelmében. Az elrettentés leginkább elterjedt formája az őrizetbe vétel. „Az őrizetbe vételek száma csökkenti a bűnözést, mert közvetlen és azonnali nyomozás-eredményességet, vagy társadalmi reagálást mutat."17 Tisztázandó mindenekelőtt az a kérdés, hogy a migráció nem azonos a bűnözéssel, a migráns nem bűnöző.

\section{Az elrettentéselmélet és a migráció kapcsolata}

Az elrettentés elméletében a tettet büntetjük, de a (neo)klasszikus paradigma már nemcsak a tettet bünteti, hanem a technikai, környezetei eszközök fejlődésével a tett elkövetését nehezíti, vagy akadályozza meg. Ezt hívjuk környezeti kriminológiának vagy szituációs bűnmegelőzésnek. Ronald W. Clarke ${ }^{18}$ amerikai kriminológus dolgozta ki az elméletet. Sokan a kriminológiai tudományos körökből, köztük maga Clarke sem tartja kriminológiának, tudománynak, mivel a bűnözés oksági összefüggéseit nem vizsgálja, és nem ad rá magyarázatot. Pusztán technikai megoldások öszszességének tartja. Tökéletesen látszik az elv megjelenése az ideiglenes műszaki határzár mint biztonságtechnikai eszköz és a megerősített jogi határzár múködésében.

\footnotetext{
Borbíró-Gönczöl-Kerezsi i. m. 754.

16 Szabó András: Az elrettentés. In Szabó András: Igazságosan vagy okosan? Budapest, Akadémiai Kiadó, 1993. 99-100.

17 Szabó (1993) i. m. 98-125.

18 Ronald W. Clarke: Situational Crime Prevention: Its Theoretical Basis and Practical Scope. Crime and Justice, 4. (1983), 225-256.
} 
$\mathrm{Az}$ állampolgárok biztonságérzetét véleményem szerint maga a kerítés felépítése nagyban megnövelte. Fontos leszögezni ismét, hogy a migráns nem bűnöző. Nem is szabad ezzel megbélyegezni. Az áldozati állapothoz közelebb áll, hiszen aki elhagyja a hazáját, az otthonát egy elképzelt szebb világ kedvéért, vagy az üldöztetés elől menekül, bárhogy is nézzük, az áldozat. Mint már írtam, a migráns fogalmába beleértem a jogi és a nem jogi kategóriákat is. Lényeges megállapítani, hogy a migráció jelensége és a migránsok szándéka, a bevándorlás eltér a bünözők magatartásától, ami a helyszínről való elmenekülés, míg ez a migránsoknál a menekültstátusz elérése. Ez a tranzitországokra mint Magyarország nem igaz. Egy nemzetállam sem engedheti meg azt, hogy szuverenitása csorbuljon akként, hogy a területén a tudta nélkül idegenek tartózkodjanak, vagy azon átkeljenek. Az államnak reagálnia kell. Ez a büntetőjog kiszélesítése új normák beemelésével. Jellemzően a már említett fogva tartás - letartóztatás - kiszélesítése, illetve meghosszabbítása lehet. Idesorolom az illegális migránsok kiutasítását vagy a tranzit zónába kísérését is, mivel szerintem dogmatikailag megfelel az izolációnak. Vagy egy meghatározott helyen lesz az illető fogva tartva, vagy az ország területéről lesz máshová „izolálva”. Hautzinger Zoltán ezt így fogalmazza meg: „A vonatkozó jogalkalmazás nem homogén a magyar jogrendszerben sem. Az illegális bevándorlás (beutazás, tartózkodás) jogkövetkezményei származhatnak büntetőjogon kívüli normákból, de megjelennek a büntetőjog rendelkezései között is. Hatékonyságánál, így különösen a jogellenes beutazásból vagy tartózkodásból származó állapot mielőbbi megszüntetéséhez fűződő társadalmi érdek primátusánál fogva elsődleges jogi instrumentumként az idegenrendészeti jog jöhet számításba." ${ }^{19}$ Majd hozzáteszi: „Az idegenrendészeti eljárás a kiutasítás kiszabásával, szükséges esetben - a menedékjogi eljárást ide nem értve - kitoloncolás alkalmazásával megszünteti a jogellenes tartózkodást minden más, az idegenrendészeti szankcióból eredő joghátrányból egyébként származó további szankció alkalmazásának lehetőségére tekintet nélkül." ${ }^{20}$

\section{A tömeges bevándorlás okozta válsághelyzet}

Magyarországon a kriminálpolitika megváltozását és az elrettentést a tömeges bevándorlás okozta válsághelyzet kihirdetése alapozta meg. Orbán Balázs megfogalmazásában: „Emberek meghatározott földrajzi területre történő magas intenzitású, nagy tömegű, kontrollálatlan - úgynevezett irreguláris migrációs mozgással bekövetkező - beáramlása. A tömeges bevándorlás okozta válsághelyzet következtében a beáramlással érintett területen megnő a politikai, gazdasági, társadalmi, kulturális feszültség, és jellemzően jelentős biztonságpolitikai kockázatok merülnek fel." ${ }^{21}$

19 Hautzinger Zoltán: Szemelvények a migráció szabályozásáról. Pécs, AndAnn Kft., 2016. 16.

20 Hautzinger (2016) i. m. 17.

21 Orbán Balázs: Bevándorlási válság. In Pásztor Péter (szerk.): Magyar politikai enciklopédia. Budapest, Mathias Corvinus Collegium - Tihanyi Alapítvány, 2019. 71. 
A tömeges bevándorlás okozta válsághelyzet Magyarország egész területére történő elrendeléséről ${ }^{22}$ a menedékjogról szóló 2007. évi LXXX. törvény (menedékjogról szóló törvény) 80/A. § (2) bekezdése kimondja, hogy az országos rendőrfőkapitány és a menekültügyi hatóság vezetőjének kezdeményezésére, az idegenrendészetért és a menekültügyért felelős miniszter javaslatára a Kormány rendeletben rendelheti el a tömeges bevándorlás okozta válsághelyzetet. A tömeges bevándorlás okozta válsághelyzet elrendelhető Magyarország meghatározott területére vagy egész területére. A Kormány a tömeges bevándorlás okozta válsághelyzet Magyarország egész területére történő elrendeléséről, valamint a válsághelyzet elrendelésével, fennállásával és megszüntetésével összefüggő szabályokról szóló 41/2016. (III. 9.) Korm. rendelettel - 2016. március 9-ei hatálybalépéssel - elrendelte Magyarország egész területére a tömeges bevándorlás okozta válsághelyzetet. A fogalomhoz hozzátartozik, hogy az érintett területen, Magyarország területén a közrend és közbiztonság fenntartását biztosító szervezetek, főképp a rendőrség feladata megnő, és ezzel együtt a létszámterheltsége is emelkedik.

\section{A magyarországi migrációt jellemző bứncselekmények okai és típusai}

Az, hogy egy állam és annak büntetőpolitikája mit tart büntetendőnek, az mindig az adott társadalom hagyományaihoz, kultúrájához, gazdasági szintjéhez kapcsolódik. Továbbá a rendészeti szervezetek büntetőügyekben mutatott eljárási intenzitása, a regisztrált ügyek száma szintén vizsgálandó, nem elhanyagolva a lakosság feljelentési hajlandóságát és bizalmát az igazságszolgáltatásban. A médiában sok olyan nyugaton elkövetett esetet látunk, amelyben migrációs háttérrel rendelkező személyekkel szemben indul el a büntetőeljárás. Ezeket mindig fenntartással kell fogadni, hisz egyformán lehet a valósághoz képest magasabb vagy alacsonyabb a cselekmények száma. Továbbá a százalékok elemzésénél rendszeresen elfeledkeznek egy fontos kriminológiai alaptételről, miszerint egy elkövető több bűncselekményt is elkövethet. Fontosnak tartom leszögezni, hogy a migráció és a terrorizmus között nincs összefüggés, csak kockázati szinten a bevándorlók, menekültek megnövekedett száma hozza magával a bűncselekmények számának lehetséges növekedését. Tekintsük át, hogy Magyarországon a 2015-ös tömeges bevándorlást követően hogyan változott meg a migráció kezelése. Magyar műszaki határzár kialakítása a szerb határon (hivatalos nevén: határőrizeti célú ideiglenes kerítés) 2015 augusztusában. A határzárhoz

\footnotetext{
22 41/2016. (III. 9.) Korm. rendelet a tömeges bevándorlás okozta válsághelyzet Magyarország egész területére történő elrendeléséről, valamint a válsághelyzet elrendelésével, fennállásával és megszüntetésével összefüggő szabályokról.
} 
kapcsolódó jogellenes cselekmények jogszabályait a Büntető Törvénykönyv XXXIV. fejezet, a közigazgatás rendje elleni bűncselekmények ${ }^{23}$ tartalmazza. Ezek nevesítve:

- határzár tiltott átlépése (Btk. 352/A);

- határzár megrongálása (352/B. §);

- határzárral kapcsolatos építési munka akadályozása (Btk. 352/C. §);

- embercsempészet (353 §);

- jogellenes bevándorlás elősegítése, támogatása (353/A. §).

Ezen jogszabályok megalapozottságát a határzár kiépülése adta. Maga a határzár nem más, mint egy fizikai akadály, amelynek elsődleges feladata a Magyarország területére történő belépés megnehezítése. Megakadályozni nem képes, időt nyer a határrendészet és a rendészeti szervezeteknek a reagálására. Az említett kriminálpolitikai bűnözéskontroll szerint ez nem más, mint a személyek izolációja, amely ebben az esetben az ország területéről történik. Az illegális átlépők visszafordítása jellemzően Szerbia felé történik, illetve a határ szerbiai részén kialakított tranzitzónába kísérik őket.

\section{A „crimmigration” megjelenésének oka és fogalma}

A „crimmigration” az illegális bevándorlás és a bevándorlási jog kriminalizálása. Ezen téma tekintetében, a bevándorlás és a menekültek jogainak kriminalizációjával kapcsolatban a jogterületet Lévay Miklós így látja: „Így a büntetőjog az egyénnek és a társadalomnak erőszak révén, csalárd módon vagy egyéb bűnös szándékkal okozott károk megelőzésére törekszik, a bevándorlási jog pedig meghatározza, hogy ki lépheti át az országhatárt, tartózkodhat adott országon belül és kinek kell elhagynia azt. A két jogterület annyiban hasonlít egymásra, hogy egyaránt különböznek más jogágaktól. Amíg ugyanis a legtöbb jogág középpontjában az egyének és az üzleti szereplők közötti kapcsolatok és konfliktusaik szabályozása áll, addig a büntetőjog és a bevándorlási jog elsősorban az állam és az egyén közötti kapcsolatot szabályozza. A büntetőjognak és a bevándorlási jognak egyaránt a lényegéhez tartoznak a befogadó és kirekesztő rendszerek. Mindkét jogterület kijelöli, hogy szükséges-e és ha igen, akkor miként befogadni, megtartani az egyéneket, mint a társadalom tagjait vagy kirekeszteni őket a társadalomból. Mindkét jogterület létrehozza a bennlévőket és a kívülállókat."24

23 2012. évi C. törvény a Büntető Törvénykönyvről.

24 Lévay Miklós: „Crimmigration” avagy kriminológiai kutatások a bevándorlás kriminalizálásáról. In Finszter Géza Korinek László - Végh Zsuzsanna (szerk.): A tudós ügyész. Tanulmányok Bócz Endre 80. születésnapjára. Budapest, HVGORAC, 2017. 154. 


\section{A migráció várható tendenciái}

A migráció minden kutatás szerint elhúzódó lesz. Hozzáteszem, bevándorlásra Európának szüksége van. Ezt Szabó A. Ferenc a fenntartható fejlődésről és a demográfiáról szóló tanulmányában járta körbe. ${ }^{25}$ Ebben szerepel egy markáns adat. A világ népessége és változásai nagyobb országok és régiók szerint (az ENSZ „közepes” becslése és előrejelzése) 1950-2050. A felmérés szerint Európa népességnövekedése 2000-2050 között $-10 \%$. Ezzel szemben a nyugati iszlám régió $+103 \%$, fekete Afrika $+152 \%$-os növekedést jelez előre. Európa és hazánk lakossága fogy és öregszik. $\mathrm{Az}$ adatok szerint Magyarországnak kellenek a bevándorlók munkavállalóknak, mert csökkenő tendenciát mutat az állampolgárainak száma, és saját erőből nem képes rövid távon ezt a kérdést megoldani. Ezt a Központi Statisztikai Hivatal által közölt számok is alátámasztják 570-600 ezer magyar tartózkodik életvitelszerủen külföldön. Az OECD 2018 júniusi jelentése 900 ezer főre teszi ezt a számot. Valójában a szám elérheti az egymillió körüli főt.

\begin{tabular}{|l|c|c|c|c|c|}
\hline & \multicolumn{3}{|c|}{ Népesség (millió) } & \multicolumn{2}{c|}{ Növekedés (\%) } \\
\hline Ország/régió & 1950 & 2000 & 2050 & $1950-2000$ & $2000-2050$ \\
\hline Észak-Amerika & 172 & 315 & 438 & 83 & 3 '9 \\
\hline Latin-Amerika & 167 & 523 & 783 & 213 & 50 \\
\hline Európa & 547 & 728 & 653 & 33 & -10 \\
\hline Nyugati iszlám régió & 148 & 545 & 1109 & 268 & 103 \\
\hline Fekete-Afrika & 180 & 670 & 1692 & 272 & 152 \\
\hline Japán & 84 & 127 & 112 & 51 & -12 \\
\hline Kína & 549 & 1259 & 1382 & 129 & 10 \\
\hline India & 358 & 1021 & 1593 & 185 & 56 \\
\hline Délkelet-Ázsia & 178 & 519 & 752 & 192 & 45 \\
\hline Ázsia-Óceánia & 128 & 379 & 562 & 196 & 48 \\
\hline Világ & 2519 & 6086 & 9076 & 142 & 49 \\
\hline
\end{tabular}

4. ábra: A világ népessége és változásai nagyobb országok és régiók szerint (az ENSZ „közepes” becslése és elörejelzése) 1950-2050. Forrás: ENSZ

\section{Konklúzió}

$\mathrm{Az}$ elrettentés, mint láttuk, egy hirtelen megváltozó állapot kezelésében nagyon jól tud múködni. Hosszú távon nem oldja meg a problémát. Az okokat nem tárja fel, és túl általánosító, vagyis az egyes ügyekben eljáró bíróságoknak kell a körülményeket

25 Szabó A. Ferenc: Fenntartható fejlődés és demográfiai problémák. Nemzet és Biztonság, 1. (2008), 4. 41. 
megfelelően feltárni. Természetesen ez a kiutasítás, illetve a tranzit zónába kísérés esetén nem igaz. Az elrettentés rövid távon hasznos, hosszú távon már nem hatékony. Fontos megjegyezni, hogy az Európai Unió és Törökország közötti egyezség sokat javított a helyzeten. De nem lehetünk optimisták. Törökország bármikor, ha csak ideiglenesen is megnyitja határait, Magyarország komoly hirtelen megnövekvő migrációval fog szembenézni. Ez még akkor is bekövetkezhet, ha a földközi-tengeri utakat lezárják, vagy megnehezítik a migránsoknak az azokon való átjutást.

A tanulmányban bemutattam a kriminálpolitika fejlődését, hogyan vált a bűnözéskontroll és a társadalomvédelem a megelőzés szolgálatába. A kriminálstatisztikai adatok azt mutatják, hogy valójában nincs a migrációhoz köthető bűnözésnövekedés. A jövő nem kiszámítható, ellenben bizonyos tendenciák mutatkoznak. Egyik oldalról a külföldi személyek által elkövetett bűncselekmények a migráció kapcsán jelenleg volumenben a határőrizeti célú ideiglenes kerítés kiépítéséhez köthetők. Ennek következménye az úgynevezett elterelődés, ${ }^{26}$ amely azt jelenti, hogy az illegális migráció nem szűnt meg, csak más irányban keresi a belépési lehetőséget az Európai Unióba. Másik oldalról a rendészeti szervezeteknek a külföldiek sérelmére elkövetett erőszakos büncselekmények megnövekedésével is számolniuk kell. A turistát, az itt tanulót vagy a vendégmunkást illegális menekültnek, terroristának nézik. Ez a jelenség a félelem az idegentől. ${ }^{27}$ Kijelenthetjük, hogy a migráció még sokáig jelen lesz életünkben. A kriminálpolitika, az elrettentés és a bevándorlás kriminalizálása, a „crimmigration” nem képesek megnyugtatóan kezelni a jelenséget. Büntetőjogi, rendészeti eszközökkel nemzetközi társadalmi jelenségeket nem lehet hosszú távon kezelni. A migráció kezelésébe bevont szervezetek létszáma még mindig alacsony egy, a 2015-ös bevándorlási hullámhoz hasonló nagyságú nyomás kezelésére. A szervezetek fejlesztése, az innováció, a digitalizáció megfelelő irány. Erre az oktatásnak is fel kell készülnie. A technika kiválthatja az embert, de a technikát kezelni és értelmezni képes embert nem válthatja ki semmi. Főképp, ha azt vesszük, hogy a migrációs eljárások személyes jelenlétet igényelnek. Csakis komplex megoldások, együttműködések és fejlesztések, amelyek nemzetközi konszenzuson alapulnak, vezethetnek eredményre. Tehát megállapítható, hogy a kriminálpolitika kapcsolata a magyar közszolgálati szervezetekkel szoros, a szervezetek múködését rövid távon segíti, azokkal összekapcsolódik. Átalakulásukat, mint ahogy a Bevándorlási és Menekültügyi Hivatal Országos Idegenrendészeti Főigazgatósággá átalakult, közigazgatási szervezetből rendőrségi szervezetté, megalapozza és generálja. A tömeges bevándorlásra adható tényleges hatékony reakciókat e szervezeteknek véges humán erőforrásból származó teljesítménye nem teszi lehetővé. Ezt csak az innováció, a fejlesztés adhatja meg, mint például biztonságtechnikai eszközök alkalmazása. Ehhez felkészült, az eszközöket alkalmazni képes szak-

26 Ritecz-Sallai (2016) i. m. 199.

27 Hautzinger Zoltán: Félelem az idegentől. In Finszter Géza - Kőhalmi László - Végh Zsuzsanna (szerk.): Egy jobb világot hátrahagyni. Tanulmányok Korinek László Professzor tiszteletére. Pécs, Pécsi Tudományegyetem Állam- és Jogtudományi Kar, 2016. 303. 
emberekre és azokat karbantartani és fejleszteni képes háttérkisegítőkre, megfelelő infrastruktúrára van szükség.

\section{FELHASZNÁLT IRODALOM}

Borbíró Andrea - Gönczöl Katalin - Kerezsi Klára - Lévay Miklós: Kriminológia. Budapest, Wolters Kluwer, 2017.

Beccaria, Cesare: A bűnökröl és a büntetésekről. Budapest, Attractor, 2012.

Christián László: A helyi rendészeti együttmüködés rendszere. Iustum Aequm Salutare, 16. (2012), 1. 33-61. Online: http://ias.jak.ppke.hu/hir/ias/20181sz/03_ChristianL_IAS_2018_1.pdf

Clarke, Ronald W.: Situational Crime Prevention: Its Theoretical Basis and Practical Scope. Crime and Justice, 4. (1983), 225-256. Online: https://doi.org/10.1086/449090

Czuprák Ottó - Kovács Gábor: A szervezetvezetés elmélete. A közszolgálati szervezetek vezetésének elméleti alapjai. Budapest, Dialóg Campus, 2017. 179.

Gönczöl Katalin - Kerezsi Klára - Korinek László: Kriminológia - Szakkriminológia. Budapest, CompLex, 2007.

Hautzinger Zoltán: Félelem az idegentől. In Finszter Géza - Kőhalmi László - Végh Zsuzsanna (szerk.): Egy jobb világot hátrahagyni. Tanulmányok Korinek László Professzor tiszteletére. Pécs, Pécsi Tudományegyetem Állam- és Jogtudományi Kar, 2016. 303.

Hautzinger Zoltán: Szemelvények a migráció szabályozásáról. Pécs, AndAnn, 2016.

Lévay Miklós: „Crimmigration” avagy kriminológiai kutatások a bevándorlás kriminalizálásáról. In Finszter Géza - Korinek László - Végh Zsuzsanna (szerk.): A tudós ügyész. Tanulmányok Bócz Endre 80. születésnapjára. Budapest, HVG-ORAC, 2017. 153-162.

Orbán Balázs: Bevándorlási válság. In Pásztor Péter (szerk.): Magyar politikai enciklopédia. Budapest, Mathias Corvinus Collegium - Tihanyi Alapítvány, 2019. 71.

Póczik Szilveszter: Nemzetközi migráció - biztonságpolitikai, rendészeti aspektusok. In Tarrósy István - Glied Viktor - Keserủ Dávid (szerk.): Új népvándorlás: Migráció a 21. században Afrika és Európa között. Pécs, Publikon, 2011. 35-51.

Ritecz György - Sallai János: A migráció trendjei, okai és kezelésének lehetőségei. 2.0. Budaörs, Hanns Seidel Alapítvány, 2016.

Szabó A. Ferenc: Fenntartható fejlődés és demográfiai problémák. Nemzet és Biztonság, 1. (2008), 4. 41.

Szabó András: Az elrettentés. In Szabó András: Igazságosan vagy okosan? Budapest, Akadémiai Kiadó, 1993. 98-125.

Szabó László András: A migráció hatása a közigazgatásra. Magyar Rendészet, 17. (2017), 1. 159-174.

\section{Internetes források}

Frontex.eu. Online: https://frontex.europa.eu/we-know/migratory-routes/western-balkan-route/h

Honvedelem.hu. Online: https://honvedelem.hu/hirek/a-magyar-honvedseg-parancsnokanak-helyettese/novelik-a-katonak-letszamat-a-hataron.html

Központi Statisztikai Hivatal. Online: www.ksh.hu

Országos Idegenrendészeti Főigazgatóság: Dublini eljárás. é. n. Online: www.bmbah.hu/index. php?option=com_k2\&view=item\&id=424\&lang=en

Rendőrség: Határrendészeti helyzetkép 2015. május-szeptember. é. n. Online: www.police. hu/a-rendorsegrol/statisztikak/hatarrendeszet?page $=6$ 


\section{Jogforrások}

2012. évi C. törvény a Büntető Törvénykönyvről

41/2016. (III. 9.) Korm. rendelet a tömeges bevándorlás okozta válsághelyzet Magyarország egész területére történő elrendeléséről, valamint a válsághelyzet elrendelésével, fennállásával és megszüntetésével összefüggő szabályokról

\section{ABSTRACT}

\section{Relationship of Criminal Policy with The Migration activities of Hungarian Public Service Organizations}

\section{László András SZABÓ}

The impact of mass immigration in 2015 is most evident in the change in criminal policy and, in this context, in the activities of administrative and law enforcement agencies dealing with migration. These organizations were basically not formed to the size and intensity of migratory pressure, either in numbers or in infrastructure. The Dublin III Regulation, signed by Hungary in January 2015, aims to accommodate two to three hundred thousand refugees throughout the European Union. In my study, I examine the relationship between Hungarian civil service organizations and the criminal policy.

Keywords: criminal policy, Public Service Organizations, mass immigration, crisis 